\title{
Previous Infection with Plasmodium berghei Confers Resistance to Toxoplasma gondii Infection in Mice
}

\author{
Dong-Hun Lee', Ki-Back Chu', Hae-Ji Kang ${ }^{1}$, Su-Hwa Lee', Fu-Shi Quan ${ }^{2,3 *}$ \\ ${ }^{1}$ Department of Biomedical Science, Graduate School, Kyung Hee University, Seoul 02447, Korea; '2Department of Medical Zoology, Kyung Hee \\ University School of Medicine, Seoul 02447, Korea; ${ }^{3}$ Medical Research Center for Bioreaction to Reactive Oxygen Species and Biomedical Science \\ Institute, School of Medicine, Graduate school, Kyung Hee University, Seoul 02447, Korea
}

\begin{abstract}
Both Plasmodium spp. and Toxoplasma gondii are important apicomplexan parasites, which infect humans worldwide. Genetic analyses have revealed that $33 \%$ of amino acid sequences of inner membrane complex from the malaria parasite Plasmodium berghei is similar to that of Toxoplasma gondii. Inner membrane complex is known to be involved in cell invasion and replication. In this study, we investigated the resistance against T. gondii (ME49) infection induced by previously infected $P$. berghei (ANKA) in mice. Levels of $T$. gondii-specific lgG, IgG1, IgG2a, and IgG2b antibody responses, $\mathrm{CD}^{+}$and $\mathrm{CD}^{+} \mathrm{T}$ cell populations were found higher in the mice infected with $P$. berghei (ANKA) and challenged with T. gondii (ME49) compared to that in control mice infected with T. gondii alone (ME49). P. berghei (ANKA) + T. gondii (ME49) group showed significantly reduced the number and size of $T$. gondii (ME49) cysts in the brains of mice, resulting in lower body weight loss compared to ME49 control group. These results indicate that previous exposure to $P$. berghei (ANKA) induce resistance to subsequent T. gondii (ME49) infection.
\end{abstract}

Key words: Toxoplasma gondii, Plasmodium berghei, inner membrane complex, T cell population, antibody response, cyst

\section{INTRODUCTION}

Malaria, a disease transmitted by mosquitoes which infects humans, has become prevalent in both the tropics and subtropical regions of the world. Malaria is the most important disease among the 6 diseases selected by the World Health Organization (WHO) due to parasitic infestations that causes about 300 to 500 million malaria infections each year, of which more than 1 million patients die [1]. Malaria is an acute febrile infectious disease caused by parasitism in red blood cells and liver cells. Symptoms associated with this disease include periodic fever, anemia, vomiting and jaundice [2].

Similar to malaria, toxoplasmosis also occurs worldwide, and infection rates do not differ between countries. Toxoplasma gondii is a common infectious organism that infects various types of mammals, including humans and it has been documented that about $1 / 3$ of all humans are exposed to this para-

\footnotetext{
- Received 10 February 2019, revised 18 March 2019, accepted 25 March 2019.

*Corresponding author (fsquan@khu.ac.kr)

(C) 2019, Korean Society for Parasitology and Tropical Medicine

This is an Open Access article distributed under the terms of the Creative Commons Attribution Non-Commercial License (http://creativecommons.org/licenses/by-nc/4.0) which permits unrestricted non-commercial use, distribution, and reproduction in any medium, provided the original work is properly cited.
}

site [3]. Once infected, T. gondii can spread to all organs such as the brain, eyes, heart, and muscles, and can lead to death in immunocompromised individuals. Pregnant individuals are also at risk as birth defects are highly plausible. To date, there is no vaccine against toxoplasmosis [4].

The inner membrane complex is made up of flattened membrane sacs termed alveoli, which are supported on the cytoplasmic face by a highly organized network of intermediate filament-like proteins known as the subpellicular network (SPN) and by interactions with the microtubule cytoskeleton. Also, the inner membrane complex has a number of important roles in the complex life cycles of these parasites [5,6], including providing structural stability, as an important scaffold in daughter cell development and as the location of the actinmyosin motor complex, a key component in parasite motility and host cell invasion $[7,8]$. Recently, understanding of the structure and components of the inner membrane complex has significantly increased with the recognition of various subdomains within the inner membrane complex and its dynamic composition throughout cell division and maturation. The functions of the inner membrane complex of Toxoplasma gondii and Plasmodium berghei are similar, but differences do exist. In T. gondii, 2 daughter buds arise from the maternal parasite 
through a process called endodyogeny, whereas multiple daughters are formed through merogony in Plasmodium spp.

Analysis of the same gene, inner membrane complex, in $P$. berghei and T. gondii showed that 33\% were similar $[9,10]$. T. gondii and Plasmodium parasites have been documented to share similar traits, especially with respect to biochemical and molecular pathways involved in pathology, immunomodulation, and metabolism [11]. This may indicate that parasites during co-infection can result in a competitive establishment that can promote or inhibit parasitological pathogenesis and fetal and birth outcomes. Yet, the disease outcome and immunological response induction as a consequence of interaction between Plasmodium and T. gondii remain largely elusive [11]. In this study, we determined the resistance to T. gondii (ME49) in mice induced by malaria P. berghei (ANKA) infection.

\section{MATERIALS AND METHODS}

\section{Parasites and animal ethics}

Female Balb/c 8 mice (7 weeks old) were purchased from KOATECH (Pyeongtaek, Korea). P. berghei (ANKA) and T. gondii (ME49) were maintained in mice by serial intraperitoneal passage. Groups of mice $(\mathrm{n}=8)$ were infected with $1 \% / 100 \mu \mathrm{l}$ of $P$. berghei (ANKA) by intraperitoneal (IP) injection. One hundred T. gondii (ME49) cyst were used to infect the mice via oral route. To determine the resistance to T. gondii infection, mice were primarily infected with Plasmodium berghei, and treated to remove malaria in the blood at day 7 . The treated mice were subsequently infected with T. gondii (ME49). All of the experimental procedures involving animals have been approved and conducted under the guidelines set out by Kyung Hee University IACUC (KHUASP [SE]-17-078).

\section{Parasite antigens preparation}

T. gondii RH tachyzoites were harvested from the peritoneal cavity of mice 4 or 5 days after infection by injecting $3 \mathrm{ml}$ of $0.1 \mathrm{M}$ phosphate buffered saline (PBS, pH 7.2) as described [13]. Peritoneal exudate was centrifuged at $100 \mathrm{~g}$ for $5 \mathrm{~min}$ at $4^{\circ} \mathrm{C}$ to remove cellular debris. The parasites in the supernatant were precipitated by centrifugation at $600 \mathrm{~g}$ for $10 \mathrm{~min}$, which were washed in PBS and sonicated. P. berghei (ANKA) antigen was prepared as described previously [14]. The P. berghei-infected red blood cells (RBCs) were collected from whole blood of mice with parasitemia exceeding $20 \%$ by low speed centrifugation $(1,500 \mathrm{rpm}, 10 \mathrm{~min})$ at $4^{\circ} \mathrm{C}$. The RBCs pellets were lysed with equal volume of $0.15 \%$ saponin in PBS for $10 \mathrm{~min}$ at $37^{\circ} \mathrm{C}$ and the released parasites were pelleted and washed 3 times with PBS $\left(13,000 \mathrm{rpm}\right.$ for $1 \mathrm{~min}$ at $\left.4^{\circ} \mathrm{C}\right)$ [15]. Parasites were sonicated twice for $30 \mathrm{sec}$ at $40 \mathrm{~Hz}$ on ice and used as coating antigens for ELISA.

\section{Assay on antibody response}

Blood samples were collected at weeks 1, 2, and 4 after challenge infection with T. gondii (ME49). T. gondii-specific IgG, IgG1 and IgG2a, IgG2b response was determined by enzymelinked immunosorbent assay (ELISA). Briefly, 96-well plates (SPL, Pocheon, Korea) were coated with $4 \mu \mathrm{g} / \mathrm{ml}$ of $T$. gondii (RH) antigen at $4^{\circ} \mathrm{C}$ overnight [17]. The plates were washed and then blocked with $0.2 \%$ gelatin in PBST for $2 \mathrm{hr}$ at $37^{\circ} \mathrm{C}$. After washing, diluted sera (1:100) samples were added and incubated for $2 \mathrm{hr}$ at $37^{\circ} \mathrm{C}$. Antibody responses were detected using the HRP-conjugated goat anti-mouse IgG [18]. The substrate O-phenylenediamine in citrate-phosphate buffer $(\mathrm{pH}$ 5.0), containing $0.03 \% \mathrm{H}_{2} \mathrm{O}_{2}$, was used to develop color and stopped with $2 \mathrm{~N} \mathrm{H}_{2} \mathrm{SO}_{4}$. The optical density at $490 \mathrm{~nm}$ was measured with an ELISA reader.

\section{Reagents}

SYBR Green I nucleic acid gel stain $(10,000 \times$ concentrate in DMSO, Cat. No. S9430) was purchased from Invitrogen (Carlsbad, California, USA). Other reagents saponin (Cat. NO 47036) were purchased from Sigma-Aldrich (St. Louis, Missouri, USA) and CD3e-PE-Cy5, CD4-FITC, CD8a-PE markers were purchased form BD Biosciences (San Jose, California, USA). Goat anti-mose IgG-HRP purchased from Southern Biotech (Birmingham, Alabama, USA).

\section{Assay on parasitemia}

For staining of infected RBC, $2 \mu \mathrm{l}$ of blood obtained from the retro-orbital plexus puncture of infected mice was collected into a 1.5-ml tube containing $100 \mu \mathrm{l}$ of a premixed stock of PBS with $500 \mathrm{U} / \mathrm{ml}$ of heparin. RBCs from P. berghei (ANKA) infected mice were stained using $1 \mu \mathrm{l}$ SYBR Green I. The samples were incubated in a dark $37^{\circ} \mathrm{C}$ incubator for $30 \mathrm{~min}$ and then flow cytometry was performed [16].

\section{T. gondii ME49 cyst count and size in the brain}

One month after infection with $T$. gondii, the brains of mice were collected and finely ground in $200 \mu \mathrm{l}$ PBS using a syringe. Approximately $5 \mu \mathrm{l}$ of homogenized brain tissue lysate was 
placed on a glass slide and observed under the microscope to count and measure the sizes of cysts [13]. All samples were counted thrice to reduce counting errors.

\section{$\mathrm{CD} 4^{+}$and $\mathrm{CD} 8^{+} \mathrm{T}$ cell responses}

$\mathrm{CD}^{+}{ }^{+}$and $\mathrm{CD}^{+}{ }^{+} \mathrm{T}$ cells populations from splenocytes of mice at 1-month post-challenge infection were analyzed by flow cytometry. Splenocytes $\left(1 \times 10^{6} \mathrm{cell} / \mathrm{ml}\right)$ in staining buffer ( $2 \%$ bovine serum albumin and $0.1 \%$ sodium azide in $0.1 \mathrm{M}$ PBS) were incubated for $15 \mathrm{~min}$ at $4^{\circ} \mathrm{C}$ with Fc Block (clone 2.4G2; BD Biosciences) [19]. For surface staining, cells were incubated with surface antibodies (CD3e-PE-Cy5, CD4-FITC, CD8a-PE, BD Biosciences) at $4^{\circ} \mathrm{C}$ for $30 \mathrm{~min}$. Splenocytes were washed with staining buffer and fixed with $4 \%$ paraformaldehyde at $4^{\circ} \mathrm{C}$ for 30 min before acquisition using BD Accuri C6 Flow Cytometer (BD Biosciences). Data were analyzed using C6 Analysis software (BD Biosciences).

\section{Statistical analysis}

All parameters were recorded for individuals within all groups. Statistical comparisons of data were carried out by 1-way ANOVA with Tukey's post hoc test or student $t$-test using PC-SAS 9.4 (SAS Institute, Cary, North Carolina, USA). A Pvalue $<0.05$ was considered to be significant.

\section{RESULTS}

\section{Parasitemia induced by $P$. berghei}

Parasitemia levels in blood were measured from all groups, including naïve mice and $P$. berghei infected mice (Fig. 1E). Mice infected with $P$. berghei showed $14 \%$ increased parasite counts (Fig. 1A, B). P. berghei parasites were not detected from mice infected with Toxoplasma gondii (ME49) alone (Fig. 1C). Absence of parasitemia was also detected from mice challengeinfected with $T$. gondii, which had previously received anti-malarial treatment to remove malaria in the blood post-P. berghei infection (Fig. 1D).

\section{T. gondii-specific antibody responses}

The T. gondii-specific antibody responses profiles in sera were determined as scheduled. P. berghei+ME49 mice induced significantly higher $T$. gondii-specific $\operatorname{IgG}$, IgG1, and IgG2a an-
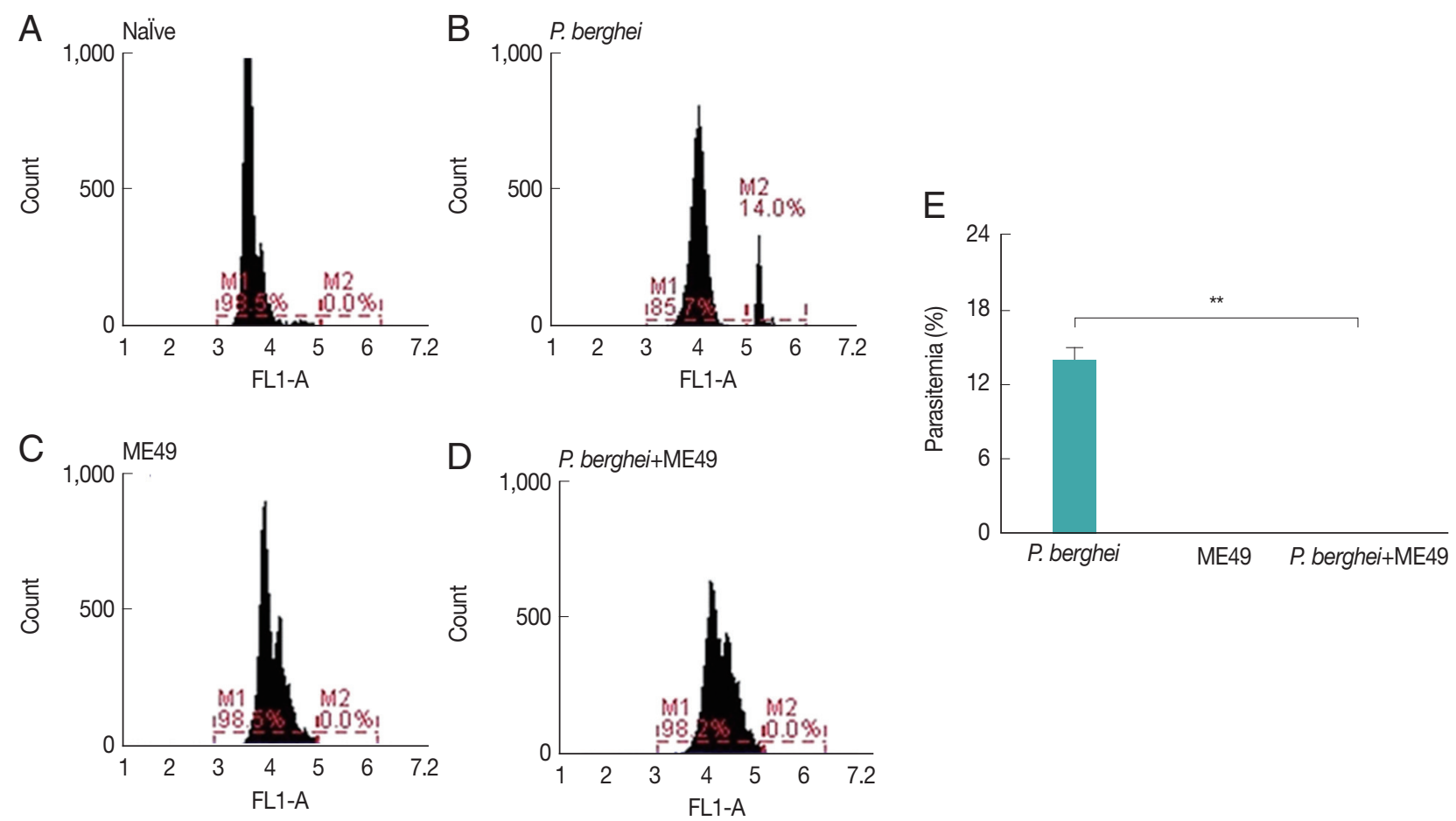

Fig. 1. Parasitemia levels in mice infected with $P$. berghei. Blood collected from infected mice were used to assess the level of parasitemia by flow cytometry. (A) Naïve mice. (B) Naïve mice infected with P. berghei. (C) Mice infected with Toxoplasma gondii. (D) Mice infected with $P$. berghei first, then subsequently infected with Toxoplasma gondii. (E) Average parasitemia per group is shown in the bar graph $\left({ }^{\star \star} P<0.01\right)$. 

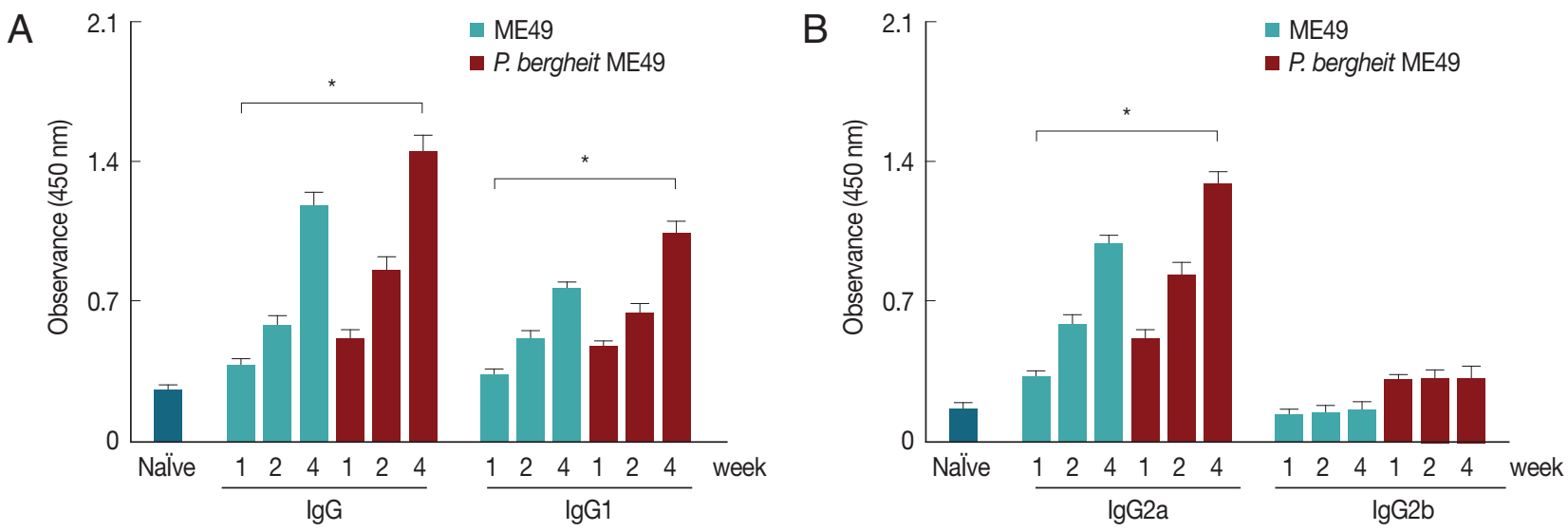

Fig. 2. Antibody response profiles against T. gondii antigen. Mice were primarily infected with $P$. berghei, and at week 4, mice were subsequently infected with T. gondii ME49. T. gondii-specific lgG, IgG1, IgG2a, and lgG2b antibody responses (A, B) in the sera were determined at weeks 1,2 , and 4 post-infection with $T$. gondii (mean \pm SD, $\left.{ }^{\star} P<0.05\right)$.

A

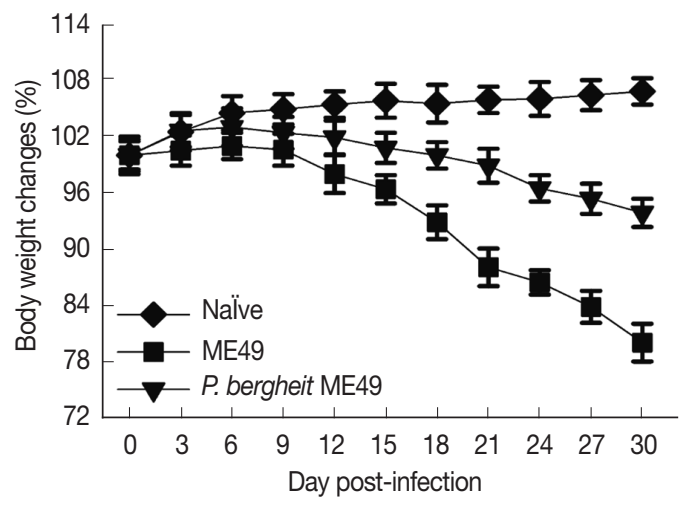

B

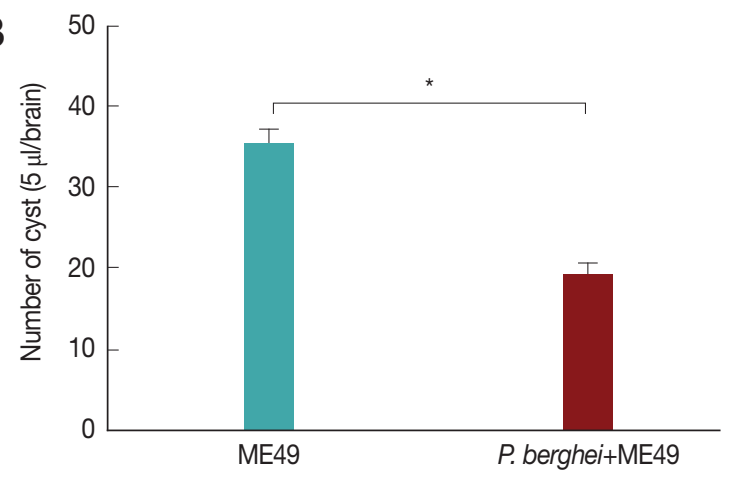

Fig. 3. Body weight changes and cyst counts in the brain. Mice were primarily infected with $P$. berghei, and at week 4, mice were subsequently infected with $T$. gondii. Mice body weight changes were recorded daily upon $T$. gondii infection and cyst counts in the $5 \mu / /$ brain were determined at 1 month after T. gondii (ME49) infection. (A) Body weight changes, and (B) cyst counts $\left({ }^{*} P<0.05\right)$.

tibody responses at weeks 1, 2, and 4 than mice infected with T. gondii alone (Fig. 2). T. gondii-specific IgG, IgG1, and IgG2a antibody responses were found to be higher at week 4 compared to those at weeks 1 or 2 in P. berghei+ME49 mice. These results indicate that T. gondii-specific $\operatorname{IgG}, \operatorname{IgG} 1$, and IgG2a antibodies were successfully boosted due to previous exposure to malaria.

\section{Previous infection with $P$. berghei shows resistance to T. gondii infection}

Fig. 3A showed that $P$. berghei+ME49 mice had a 15\% less reduction in body weight compared to mice infected with $T$. gondii (ME49) alone. In addition, in Fig. 3B, the number of $T$. gondii (ME49) cysts in 4 mice infected with $P$. berghei also decreased by $55 \%$. As shown in Fig. 4C, 4 mice infected with $P$. berghei (ANKA) showed a 38\% reduction in cyst size compared to mice infected with ME49 alone. The average cyst size was about $52 \mu \mathrm{m}$ in the ME49-infected mice (Fig. 4A), whereas the cyst size was about $20 \mu \mathrm{m}$ in the ME49-infected mouse which had previous exposure to $P$. berghei (Fig. 4B). This suggests that previous infection with $P$. berghei (ANKA) confers resistance to infection with T. gondii (ME49).

Previous infection with $P$. berghei shows $\mathrm{CD} 4^{+}$and $\mathrm{CD} 8^{+}$ $T$ cell responses upon challenge infection with $T$. gondii

$\mathrm{CD} 4^{+} \mathrm{T}$ and $\mathrm{CD} 8^{+} \mathrm{T}$ cell responses are important indicators for assessing immunity induced by infection. $\mathrm{CD} 4^{+} \mathrm{T}$ and $\mathrm{CD} 8^{+}$ $\mathrm{T}$ cell responses were determined after sacrifice. As seen in Fig. $5, \mathrm{CD}^{+}$and $\mathrm{CD} 8^{+} \mathrm{T}$ cell populations in mice infected with $\mathrm{T}$. gondii (ME49) were $26.3 \%$ and $21.5 \%$ respectively, whereas these populations levels were significantly increased to $32.4 \%$ and $25.1 \%$ in mice previously infected with P. berghei (ANKA) 
A

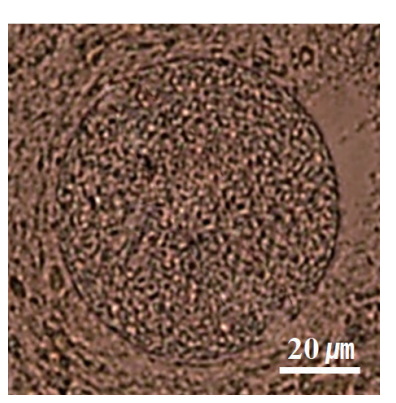

B

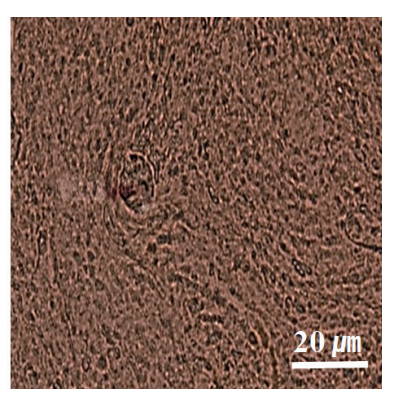

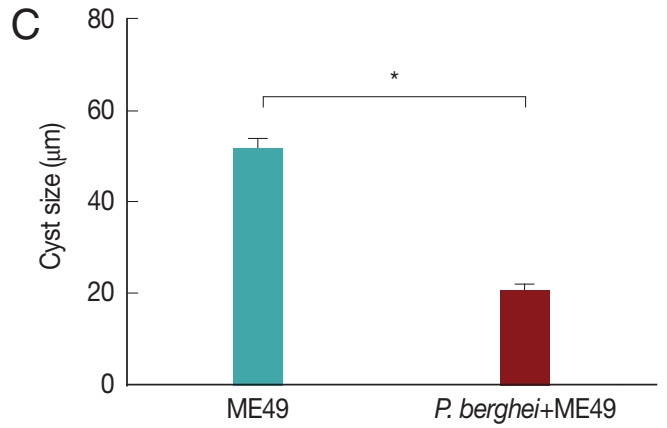

Fig. 4. Cysts size of Toxoplasma gondii (ME49) in the brain. Mice were sacrificed at 1 month after infection with $T$. gondii, and cysts were observed in the brain under microscopy. (A) T. gondii (ME49) infection control. (B) Mice infected with $P$. berghei were subsequently infected with T. gondii malaria. (C) Ten cysts from 1 mouse brain were observed $(n=4)\left({ }^{*} P<0.05\right)$.
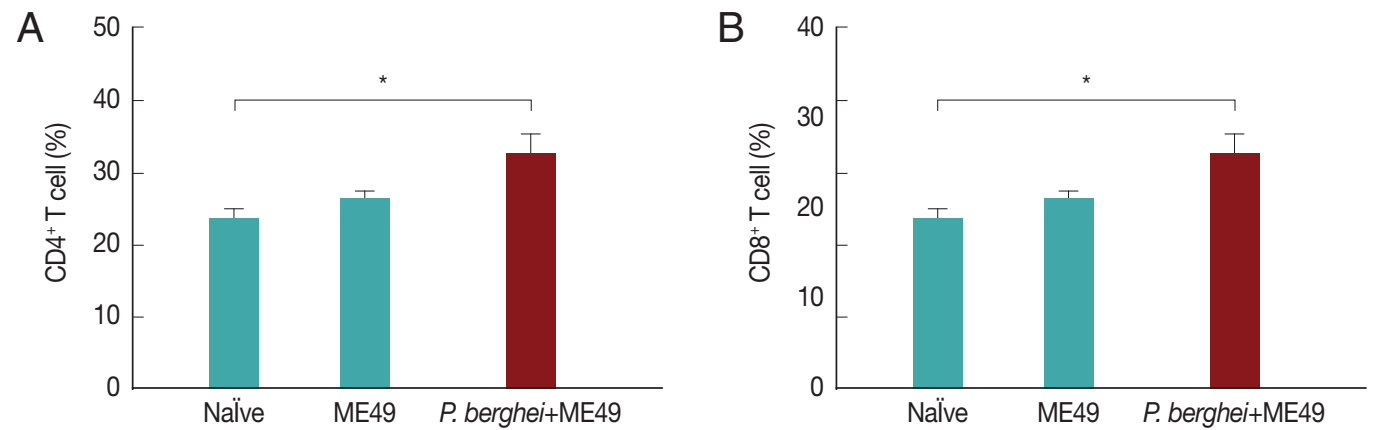

Fig. 5. $T$ cell responses. Mice were sacrificed at 1 month after $T$. gondii (ME49) infection. CD4 ${ }^{+} T$ cells and $C D 8^{+} T$ cell populations were measured in the spleen $\left(A, B ;\right.$ mean $\left.\pm S D,{ }^{*} P<0.05\right)$.

(Fig. 5). These results indicate that T. gondii (ME49) infected with $P$. berghei (ANKA) induces more $T$ cell responses.

\section{DISCUSSION}

In this study, we assessed the resistance against Toxoplasma gondii (ME49) in mice previously infected with $P$. berghei and $T$. gondii $[9,20]$. Our results indicate that $T$. gondii-specific IgG, IgG1, IgG2a antibody responses, along with $\mathrm{CD} 4^{+}$and $\mathrm{CD} 8^{+} \mathrm{T}$ cell responses contributed to resistance against infection with T. gondii. As far as we know, this is the first report documenting resistance against $T$. gondii reinfection in $P$. berghei after treatment. P. berghei (ANKA) used for malaria infection was found to be very important for inhibiting T. gondii (ME49) [21]. In our study, T. gondii (ME49) infection induced greater T. gondiispecific IgG antibody response in mice which had received treatment post-P. berghei infection than control. Specific IgG antibody response detected against $P$. berghei was also greater than those detected from T. gondii control mice. Compared to the first week after infection with T. gondii (ME49), T. gondii- specific IgG responses doubled by week 4 . Antigen-specific IgG1 response was only detected against $T$. gondii but not $P$. berghei. In malaria, IgG2a antibodies are primarily involved in controlling parasite infestation. When red blood cells become infected in the early stages of rodent malaria, macrophages are induced. It is possible that activated macrophages stimulate production of IgG2a antibodies, which preferentially attack merozoite-infected RBCs. IgG2a antibody provides important protection from malaria infection, whereas IgG1 antibody does not play an important role in protection [22]. Toxoplasma gondii infection induces a potent, protective Th1 immune response characterized by production of IFN- $\gamma$, IL-12 cytokines and IgG2a antibodies. The Th1 immune response induced during $T$. gondii infection is produced by IL-12 secreted from APC. IL-12 and IFN- $\gamma$ may also have an impact on the Th2 immune response. T. gondii infection limits the parasite-specific Th2 immune response and induces a Th1 immune response [23]. In addition, marked reduction of brain cyst count was observed and these results can be attributed to enhanced humoral immunity induced upon co-infection [24]. Our results 
have demonstrated that lesser degree of body weight reduction was observed in mice infected with both $P$. berghei (ANKA) and $T$. gondii, in comparison to those infected with $T$. gondii (ME49) alone. Compared to T. gondii (ME49) control groups, $\mathrm{CD}^{+} \mathrm{T}$ and $\mathrm{CD} 8^{+} \mathrm{T}$ cell levels were elevated in co-infected mice by $6.1 \%$ and $3.6 \%$, respectively [25]. Malaria infection involves accumulation of inflammatory cytokines such as TNF- $\alpha$, IL-1, IFN- $\gamma$ and IL- 6 along recruitment of various innate immune cells, including but not limited to inflammatory mononuclear cells, macrophages, DCs, and NK cells. IL-12 mediated induction of highly activated parasite-specific $\mathrm{CD} 4^{+}$ T cells expressing IFN- $\gamma$ (Th1) is also a key to protection against Plasmodium infection [26]. T. gondii infection induces the expression of inflammatory cytokines, including IL-12, IL- 6 and TNF- $\alpha$. IL-12 differentiates CD4 ${ }^{+}$T cells into Th1 strains and stimulates IFN- $\gamma$ release by NK cells in combination with other inflammatory cytokines such as IL-18 and IL1 , which further exacerbates inflammation [27]. The appropriately activated phagocytes respond by secreting IL- 12 , TNF- $\alpha$, IL-6, and IL-1 which leads to phagocytosis of parasite-infected host cells. It also activates immune cells such as NK cells and T cells. In second lymphoid tissues, inflammatory cytokine expression continues and parasite antigens are presented on $\mathrm{CD}^{+}$and $\mathrm{CD} 8^{+} \mathrm{T}$ cells, leading to $\mathrm{T}$ cell activation and proliferation. In particular, IL-12 induces $\mathrm{CD} 4{ }^{+} \mathrm{T}$ cells to differentiate into potent Th1 cells that secrete large amounts of IFN- $\gamma$ when activated. Th1 cells and inflammatory cytokines further activate $\mathrm{CD} 8^{+} \mathrm{T}$ cells [10]. Combining these results, resistance against $T$. gondii (ME49) due to the activity of Th1 was found through co-infection of P. berghei and T. gondii, which involves contribution from both cellular and humoral immunity.

\section{ACKNOWLEDGMENT}

This work was supported by grants from the National Research Foundation of Korea (NRF) (2018R1A2B6003535, 2018 R1A6A1A03025124).

\section{CONFLICT OF INTEREST}

The authors have no conflicts of interest to declare.

\section{REFERENCES}

1. World Health Organization. Water-related Diseases: Malaria [In- ternet]; [Retrieved 5 Dec 2018]. Available from: https://www. who.int/water_sanitation_health/diseases-risks/diseases/malaria/en/.

2. Mueller I, Shakri AR, Chitnis CE. Development of vaccines for Plasmodium vivax malaria. Vaccine 2015; 33: 7489-7495.

3. Lee DH, Kim AR, Lee SH, Quan FS. Cross-protection induced by Toxoplasma gondii virus-like particle vaccine upon intraperitoneal route challenge. Acta Trop 2016; 164: 77-83.

4. Lee SH, Kim AR, Lee DH, Rubino I, Choi HJ, Quan FS. Protection induced by virus-like particles containing Toxoplasma gondii microneme protein 8 against highly virulent RH strain of Toxoplasma gondii infection. PLoS One 2017; 12: e0175644.

5. Kono M, Herrmann S, Loughran NB, Cabrera A, Engelberg K, Lehmann C, Sinha D, Prinz B, Ruch U, Heussler V. Evolution and architecture of the inner membrane complex in asexual and sexual stages of the malaria parasite. Mol Biol Evol 2012; 29: 2113-2132.

6. Ouologuem DT, Roos DS. Dynamics of the Toxoplasma gondii inner membrane complex. J Cell Sci 2014; 127: 3320-3330.

7. Lee DH, Lee SH, Kim AR, Quan FS. Virus-like nanoparticle vaccine confers protection against Toxoplasma gondii. PLoS One 2016; 11: e0161231.

8. Parkyn Schneider M, Liu B, Glock P, Suttie A, McHugh E, Andrew D, Batinovic S, Williamson N, Hanssen E, McMillan P, Hliscs M, Tilley L, Dixon MWA. Disrupting assembly of the inner membrane complex blocks Plasmodium falciparum sexual stage development. PLoS Pathog 2017; 13: e1006659.

9. Harding CR, Meissner M. The inner membrane complex through development of Toxoplasma gondii and Plasmodium. Cell Microbiol 2014; 16: 632-641.

10. Butler NS, Harris TH, Blader IJ. Regulation of immunopathogenesis during Plasmodium and Toxoplasma infections: more parallels than distinctions? Trends Parasitol 2013; 29: 593-602.

11. Onkoba NW, Chimbari MJ, Mukaratirwa S. Malaria endemicity and co-infection with tissue-dwelling parasites in Sub-Saharan Africa: a review. Infect Dis Poverty 2015; 4: 35.

12. Mengs $U$, Pelster B. The course of Plasmodium berghei infection in mice latently infected with Toxoplasma gondii. Experientia 1982; 38: 570-571.

13. Kang HJ, Lee SH, Chu KB, Lee DH, Quan FS. Virus-like particles expressing Toxoplasma gondii rhoptry protein 18 induces better protection than rhoptry protein 4 against $T$. gondii infection. Korean J Parasitol 2018; 56: 429-435.

14. Fairlie-Clarke KJ, Lamb TJ, Langhorne J, Graham AL, Allen JE. Antibody isotype analysis of malaria-nematode co-infection: problems and solutions associated with cross-reactivity. BMC Immunol 2010; 11: 6.

15. Cao Y, Zhang D, Pan W. Construction of transgenic Plasmodium berghei as a model for evaluation of blood-stage vaccine candidate of Plasmodium falciparum chimeric protein 2.9. PLoS One 2009; 4: e6894.

16. Somsak V, Srichairatanakool S, Yuthavong Y, Kamchonwongpaisan S, Uthaipibull C. Flow cytometric enumeration of Plasmodium berghei-infected red blood cells stained with SYBR Green I. 
Acta Trop 2012; 122: 113-118.

17. Susanto L, Muljono R. Preparation of Toxoplasma gondii RH strain antigen, antigen analysis and antigen detection in sera: a review. Southeast Asian J Trop Med Public Health 2001; 32: 195201.

18. Lee SH, Lee DH, Piao Y, Moon EK, Quan FS. Influenza M1 viruslike particles consisting of Toxoplasma gondii rhoptry protein 4 . Korean J Parasitol 2017; 55: 143-148.

19. Chu KB, Lee DH, Kang HJ, Quan FS. The resistance against Trichinella spiralis infection induced by primary infection with respiratory syncytial virus. Parasitology 2019; 146: 634-642.

20. Rifaat MA, Salem SA, Azab ME, el-Razik IA, Safer EH, Beshir SR, el-Shennawy SF. Experimental concomitant toxoplasma and malaria infection in rats. Folia Parasitol 1984; 31: 97-104.

21. Omata Y, Nakabayashi T, Suzuki N. Different appearance of parasitized erythrocytes in blood between normal and toxoplasmainfected rats after infection of Plasmodium berghei. Zentralbl Bakteriol Orig A 1979; 244: 362-373.

22. White WI, Evans CB, Taylor DW. Antimalarial antibodies of the immunoglobulin G2a isotype modulate parasitemias in mice infected with Plasmodium yoelii. Infect Immun 1991; 59: 35473554.
23. Ahmed N, French T, Rausch S, Kühl A, Hemminger K, Dunay IR, Steinfelder S, Hartmann S. Toxoplasma co-infection prevents Th2 differentiation and leads to a helminth-specific Th1 response. Front Cell Infect Microbiol 2017; 7: 341.

24. Chew WK, Segarra I, Ambu S, Mak JW. Significant reduction of brain cysts caused by Toxoplasma gondii after treatment with spiramycin coadministered with metronidazole in a mouse model of chronic toxoplasmosis. Antimicrob Agents Chemother 2012; 56: $1762-1768$.

25. Charest H, Sedegah M, Yap GS, Gazzinelli RT, Caspar P, Hoffman SL, Sher A. Recombinant attenuated Toxoplasma gondii expressing the Plasmodium yoelii circumsporozoite protein provides highly effective priming for CD8+ T cell-dependent protective immunity against malaria. J Immunol 2000; 165: 2084-2092.

26. Ademola IO, Odeniran PO. Co-infection with Plasmodium berghei and Trypanosoma brucei increases severity of malaria and trypanosomiasis in mice. Acta Trop 2016; 159: 29-35.

27. Santiago HC, Oliveira MA, Bambirra EA, Faria AM, Afonso LC, Vieira LQ, Gazzinelli RT. Coinfection with Toxoplasma gondii inhibits antigen-specific Th2 immune responses, tissue inflammation, and parasitism in BALB/C mice infected with Leishmania major. Infect Immun 1999; 67: 4939-4944. 
